University of Nebraska - Lincoln

DigitalCommons@University of Nebraska - Lincoln

USDA National Wildlife Research Center - Staff Publications
U.S. Department of Agriculture: Animal and Plant Health Inspection Service

November 2019

\title{
Male Burmese pythons follow female scent trails and show sex- specific behaviors
}

\author{
Shannon A. Richard \\ James Madison University \\ Eric A. Tillman \\ National Wildlife Research Center, Florida Field Station, U.S. Department of Agriculture \\ John S. Humphrey \\ National Wildlife Research Center, Florida Field Station, U.S. Department of Agriculture \\ Michael L. Avery \\ National Wildlife Research Center, Florida Field Station, U.S. Department of Agriculture \\ M. Rockwell Parker \\ James Madison University, mrockwellparker@gmail.com \\ Follow this and additional works at: https://digitalcommons.unl.edu/icwdm_usdanwrc \\ Part of the Natural Resources and Conservation Commons, Natural Resources Management and \\ Policy Commons, Other Environmental Sciences Commons, Other Veterinary Medicine Commons, \\ Population Biology Commons, Terrestrial and Aquatic Ecology Commons, Veterinary Infectious Diseases \\ Commons, Veterinary Microbiology and Immunobiology Commons, Veterinary Preventive Medicine, \\ Epidemiology, and Public Health Commons, and the Zoology Commons
}

Richard, Shannon A.; Tillman, Eric A.; Humphrey, John S.; Avery, Michael L.; and Parker, M. Rockwell, "Male Burmese pythons follow female scent trails and show sex-specific behaviors" (2019). USDA National Wildlife Research Center - Staff Publications. 2296.

https://digitalcommons.unl.edu/icwdm_usdanwrc/2296

This Article is brought to you for free and open access by the U.S. Department of Agriculture: Animal and Plant Health Inspection Service at DigitalCommons@University of Nebraska - Lincoln. It has been accepted for inclusion in USDA National Wildlife Research Center - Staff Publications by an authorized administrator of DigitalCommons@University of Nebraska - Lincoln. 


\title{
ORIGINAL ARTICLE
}

\section{Male Burmese pythons follow female scent trails and show sex- specific behaviors}

\author{
Shannon A. RICHARD, ${ }^{1}$ Eric A. TILLMAN, ${ }^{2}$ John S. HUMPHREY, ${ }^{2}$ Michael L. AVERY ${ }^{2}$ and M. \\ Rockwell PARKER ${ }^{1}$ \\ ${ }^{1}$ Department of Biology, James Madison University, Harrisonburg, Virginia, USA and ${ }^{2}$ National Wildlife Research Center, Florida \\ Field Station, U.S. Department of Agriculture, Gainesville, Florida, USA
}

\begin{abstract}
Animals communicate with potential mates using species-specific signals, and pheromones are powerful sexual signals that modify conspecific behavior to facilitate mate location. Among the vertebrates, snakes are especially adept in mate searching via chemical trailing, which is particularly relevant given that many snake species are invasive outside their native ranges. Chemical signals used in mate choice are, thus, potentially valuable tools for management of invasive snake species. The Burmese python (Python bivittatus) is an invasive snake in the Florida Everglades where it is negatively impacting native fauna. In this study, we sought to: (i) determine if males can follow conspecific chemical trails in a Y-maze; and (ii) describe the mate searching behaviors exhibited by males while trailing. All males consistently followed a single female scent trail in the maze, but when only a male scent trail was present they did not discriminate between the male and blank arms. Rate of tongue-flicking, a proxy for chemosensory sampling, was also marginally higher when males were following female versus male scent trails. However, when both female and male scent trails were simultaneously present in the Y-maze, males did not show a preference for the female arm, although the tongue-flick rate was higher in the female-only trial compared to female versus male. Analyses of multiple male behaviors individually and using an ethogram revealed that behaviors were more frequent and complex in the female-only trials compared to male-only trials. Additional behavioral trials are needed to determine if an effective pheromonal approach to Burmese python management is possible.
\end{abstract}

Key words: chemical ecology, invasive species, pheromone, snake, trailing

\section{INTRODUCTION}

Animals use scent as a powerful form of sexual signaling that elicits robust, sex-specific behaviors in con-

Correspondence: M. Rockwell Parker, MSC 7801 Bioscience, 951 Carrier Drive, Harrisonburg, VA 22807, USA.

Email: mrockwellparker@gmail.com specifics and relays valuable information about the signaler. For example, male field crickets (Gryllus bimaculatus De Geer, 1773) can determine sex and age from chemicals in the cuticle that prompt either courtship (female odor) or aggression (male odor) (Nagamoto $e$ al. 2005). In vertebrates, a variety of sex-specific behaviors have been documented in response to sexual chemical signals, such as the classic flehmen response in male mammals exposed to female scent that also chang- 
es based on female reproductive state (e.g. Rasmussen et al. 1982). In leopard geckos [Eublepharis macularius (Blyth , 1854)], males attack conspecifics of either sex when they produce masculine scent, which occurs after treatment with male sex hormones (Rhen \& Crews 2000). The sexual odors prompting such specific behaviors can be isolated and identified as pheromones, which facilitates both basic and applied research.

Reproductive chemical signals are useful to wildlife managers focused on invasive species because of the strong behavioral effects they stimulate. Many invasive insect species can be effectively controlled through pheromone-based mediation, and, more recently, pheromones have shown significant promise in controlling vertebrate pest species (Witzgall et al. 2010; Takács et al. 2017). Furthermore, many other sexual signals are important in mate searching and assessment and have been manipulated by researchers, such as visual lures for pest insects, acoustic traps for fish, and combination lures using visual and acoustic cues for pest bird species (Eriksson \& Wallin 1986; Lelito et al. 2008; Moynan et al. 2016). Across invasive animals, chemical cues have been the most successful type of signals adapted as tools for management (Witzgall et al. 2010).

Reptiles rely heavily on reproductive chemical signals in mate tracking and assessment, and many species are currently invasive or have significant invasion potential. Of all groups of reptiles, chemical communication is most well-documented in snakes, especially mate searching and courtship (Mason 1992; Parker \& Mason 2011). Furthermore, the chemical cues used by snakes in mate choice can be tested robustly in both the field and the laboratory (Mason et al. 1998; Parker \& Mason 2011). Finally, male snakes use female scent trails to locate mates but also to ascertain multiple female qualities, such as size and condition (Ford 1986; Mason et al. 1989; Shine et al. 2003).

There is potential to develop chemical lures for management of invasive snake species, yet the chemical ecology of just a single species, brown treesnake [Boiga irregularis (Merrem, 1802)], has been detailed (Greene \& Mason 1998; Greene et al. 2001; Mathies et al. 2013). The Burmese python (Python bivittatus Kuhl, 1820) is an invasive snake in the Florida Everglades that is seriously impacting local ecological systems (Engeman et al. 2011; Dorcas et al. 2018). These giant constrictors are directly implicated in significant reductions in local mammal populations and cause concern for multiple endangered species (Dorcas et al. 2012; Green et al. 2007; Snow et al. 2007; McCleery et al. 2015). Several factors contribute to the success of Burmese pythons in the Everglades, notably their high reproductive potential, large size, and generalist diet (Reed et al. 2012).

Studying the chemical ecology of the Burmese python is a promising avenue for research given that other species of pythons use chemical cues in mate tracking. Male carpet pythons (Morelia spilota imbricata Smith, 1981) discriminate female scent trails (Bryant et al. 2011). Males of another python species (Liasis mackloti Duméril \& Bibron, 1844) trail conspecifics in a maze and discriminate between subspecies (Carmichael et al. 2007). Establishing that Burmese pythons use chemicals for communication is an important step in understanding the role of such signaling in this invasive species and will prove useful in future tests of python-derived chemical cues for potential field applications.

\section{MATERIALS AND METHODS}

\section{Animals and husbandry}

Male $(n=6)$ and female $(n=2)$ Burmese pythons ( $P$. bivittatus) were caught in the Florida Everglades and transported to the U.S. Department of Agriculture (USDA) National Wildlife Research Center (NWRC) field station in Gainesville, Florida. We maintained snakes in individual outdoor pens $(1.5 \times 3 \times 1.8 \mathrm{~m})$ at ambient conditions in accordance with guidelines established by the NWRC IACUC and the Florida Fish and Wildlife Conservation Commission. One male died before all trials were completed, reducing the sample size to $n=5$ for the male-only and male versus female trials.

\section{Y-maze trials}

We used a Y-maze to determine how male Burmese pythons ( $n=6$ for female only trials; $n=5$ for male only and male $v s$ female trials) responded to conspecific scent trails (Fig. 1). The Y-maze had an initial 1.4-m passageway leading from the start box, ending at a $45^{\circ}$ Y-junction from which two $1.2 \mathrm{~m}$ passageways (designated North and South) led to collection boxes (plastic storage bins). The maze was attached to a $2.4 \times 2.4 \mathrm{~m}$ "Hardie board" base. The arms of the maze were made of $2.5 \times 15.2-\mathrm{cm}$ PVC side boards. The maze was secured within a locked outdoor pen $(6.1 \times 3 \times 1.8 \mathrm{~m})$ to ensure no python escaped. We erected a canopy over the testing pen to shelter the maze and surveillance cameras from rain and direct sun. We conducted trials between 1300 hours and 1900 hours from 18 April 2017 to 24 August 2017. 
Mating in Burmese pythons in south Florida occurs during December-April when breeding aggregations are observed (Smith et al. 2016). Egg-laying is generally in May and June (Harvey et al. 2008). Ambient temperatures in Gainesville, Florida are too cool for pythons to be active as early in the calendar year as in south Florida, so we initiated trials during April when average temperatures resemble those during December-January in the Everglades (U.S. Climate Data: https://usclimatedata.com/climate/gainesville/florida/united-states/ usfl0163). Pythons were fed according to appetite and activity levels as per our IACUC protocol. Food was offered once per week (March to May) or twice per week (June to August). Test pythons (stimulus and focal) were not fed on the day prior to their trial to avoid post-prandial lethargy, and food was then offered after testing was completed.

Initial trials were bias tests with no scent in the Y-maze to determine if snakes showed a preference for either arm of the maze (3/6 chose the $\mathrm{N}$ arm; $P$ $=0.5$ ). The 3 experimental trials were: (i) male-only (male scent trail in base and 1 arm; other blank); (ii) female-only (female scent trail); and (iii) male versus female (both present in maze). For each trial type, the stimulus python providing the scent trail moved freely through the base of the Y-maze and only 1 arm (the other was blocked with a partition then removed for the trial) at their own pace without our intervention. We let stimulus snakes create trails in this way to simulate

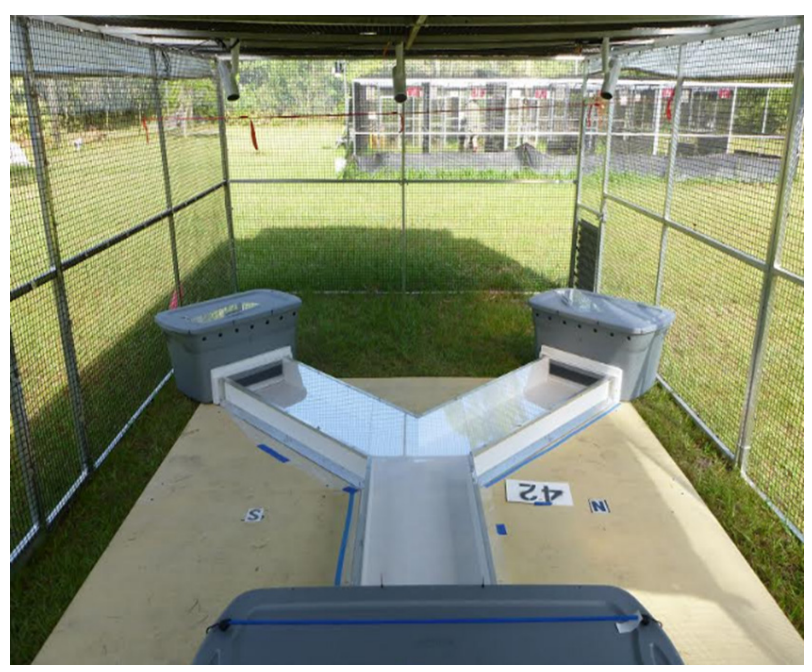

Figure 1 Y-maze located in Gainesville, Florida used in the trials. scent deposition in the natural environment and to minimize stress on the stimulus animals that may affect the quality of the trail. In the male versus female trials, the male scent trail was deposited first, then the female; a partition along the length of the base arm separated the male and female trails as they were deposited. The arm containing the scent was randomized for every trial via coin toss. To start each trial, the trailing male was acclimated for $30 \mathrm{~min}$ in the holding box at the base of the maze and then allowed to enter. The trial was completed when the male's head entered a holding box in either arm.

We tested each male twice within each trial type and assigned male test order randomly. The length of the intertrial period per male ranged from 3 to 28 days. For the female-only and male versus female trials, each male was matched with each of the 2 females. In the male-only trials, each male was randomly matched with 2 of the other males. Individual male responses were then averaged per trial type. The order for the trial types was prioritized to run female-only first at the time when Burmese pythons in the Everglades are most reproductively active (December-April; Smith et al. 2016). The female-only trials were run from 18 April to 19 May 2017, male-only was from 22 May to 9 June 2017, and male versus female from 15 June to 18 July 2017. This order was also prioritized because of the technical challenges in running the stimulus python through the maze to deposit a scent trail, especially in the female-only and male versus female trials.

For each trial, we covered the floor of the maze with a plastic sheet and then a piece of clean white paper. Between trials, we replaced the paper and sheeting and disassembled and washed the maze components and holding boxes with soap (Micro laboratory cleaner) and water to eliminate residual odor cues. After the stimulus python completed its run, we washed and dried the start box and the partitions used in the maze and did so prior to placing the next snake in the box.

\section{Data collection}

We monitored each trial with digital surveillance cameras at 3 different angles: one facing the base arm and holding box and one facing down each arm from the Y-junction to the holding boxes. Video was recorded to DVR, and video files were analyzed at James Madison University in Harrisonburg, Virginia to quantify male python behaviors: arm choice, choice penalty score, tongue-flick rate (tongue-flicks per minute), pauses, head raises, head shakes and turns (Table 1). Choice 
Table 1 List of behaviors recorded when male Burmese pythons followed conspecific scent trails in a Y-maze

\begin{tabular}{ll}
\hline Behavior & Description \\
\hline Pause & Stops moving for longer than $3 \mathrm{~s}$ while trailing \\
Head shake & Moves head laterally, side-to-side approximately $5 \mathrm{~cm}$; usually occurs as a rapid series of movements \\
Head raise & Lifts head above the substrate and cranes upward \\
Turn & Change in the direction of movement by $90^{\circ}$ to either the left or right \\
\hline
\end{tabular}

was determined when the male's head entered a holding box in either arm. Choice penalty scores were assigned by dividing each arm into five $30-\mathrm{cm}$ segments and giving 1 negative point for each segment the male entered in the non-target arm (blank arm in male-only and female-only trials; male arm in the male-female trials). Tongue-flick rate was recorded as tongue-flicks per minute when visible in the recordings. Behaviors were counted and time between sequential behaviors (sec) was recorded.

\section{Data analysis}

For choice data, we used binomial tests but did not statistically compare choice across the trial types; this analysis approach is common in Y-maze experiments (Parker \& Mason 2011). Tongue-flick rate, choice penalty score and individual behaviors were analyzed using one-way repeated measures ANOVA followed by Bonferroni-corrected $t$-tests. To establish ethograms linking individual behaviors, a single behavior was considered to follow another if they occurred within $20 \mathrm{~s}$ of one other. The frequency of each sequence was recorded. Head shakes would often occur in series, so we recorded each as a single incidence to follow the guidelines of Slater (1973) for describing behavioral sequences.

\section{RESULTS}

Male Burmese pythons ( $n=6$ for female scent trials, $n=5$ for male scent trials) showed significant trailing preference for female scent trails $(11 / 11$ trials; $P<0.001)$ but did not follow male scent $(4 / 10$ trials; $P=0.37)$ in the Y-maze (Fig. 2). In the male-only trials, $3 / 5$ males chose the male arm, with 1 male choosing the male arm in both trials. When given the simultaneous choice between male and female scent trails, males did not prefer female scent $(4 / 10$ trials; $P=0.37)$. In those trials, $3 / 5$ males chose the female scent trail, with 1 male choosing the female trail both times. We also re-ran the fe- male-only trial during 7-24 August 2017 and obtained a different result ( $7 / 10$ chose the female arm; $P=0.17)$. In those trials, males consistently followed 1 female's scent trail $(5 / 5$ trials; $P<0.001)$, and she was the larger of the 2 females. Choice penalty scores differed across the trials $\left(F_{2,8}=4.84, P=0.042\right)$ and were most negative in the male-only $(-3.0 \pm 0.93 \mathrm{SEM})$ and male versus female trials $(-3.20 \pm 0.78)$ compared to the female-only trials $(-0.50 \pm 0.27 ; q=3.65, P=0.033 ; q=$ $3.94, P=0.055$, respectively) (Fig. 3). Therefore, males explored the non-target arm the least in the female-only trials (male-only $v s$ male-female, $q=0.29, P=0.84$ ). In all but 1 of the trials, the stimulus python(s) providing the scent trail never defecated in the maze; therefore, the scent trails were produced passively as pythons moved

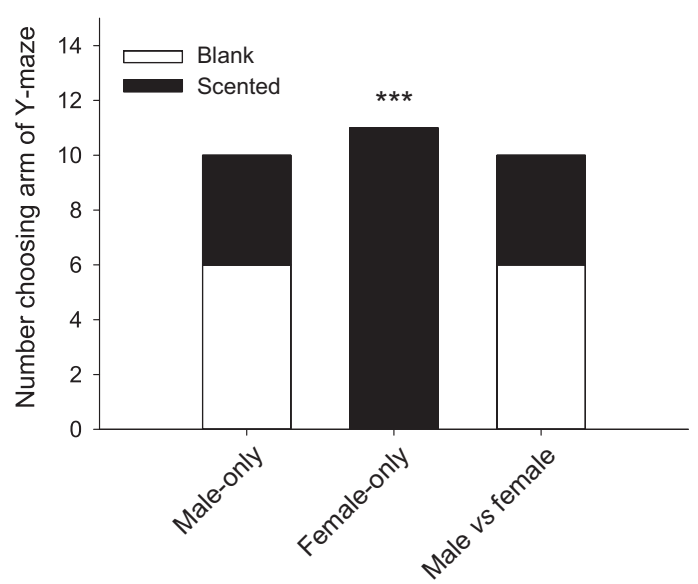

Figure 2 Arm choice in a Y-maze by male Burmese pythons. Males $(n=5$ in male-only and male $v s$ female; $n=6$ in female-only) showed a significant preference for female scent trails $(P<0.001)$ but not male scent trails compared to the unscented arm. Each male was run twice in each trial. When given the choice between male and female scented arms, the pythons showed no preference (4/10 chose the female arm). 
through the maze, as is common in all other snake species tested in conspecific trailing (Parker and Mason 2011).

When trailing, males exhibited a higher rate of tongue-flicking (RTF, tongue-flicks per $\mathrm{min}$ ) to female scent in the female-only and male $v s$ female trials compared to male-only $\left(F_{2,8}=4.76, P=0.043\right)$ (Fig. 4). Male RTF was higher in female-only $(66.52 \mathrm{TFs} / \mathrm{min} \pm$ 4.51 SEM) compared to male $v s$ female $(55.1 \pm 5.48 ; q$ $=3.71, P=0.031)$ and marginally higher than male-only $(54.74 \pm 5.61 ; q=3.84, P=0.061)$ (male-only $v s$ male-female, $q=0.134, P=0.92)$. Trailing times did not differ across the trials $\left(F_{2,8}=2.23, P=0.16\right.$; male-on$\mathrm{ly}=2.6 \mathrm{~min} \pm 0.27$; female-only $=4.23 \pm 0.63$; male-female $=4.7 \pm 0.98$ ).

Males displayed distinct, quantifiable behaviors (Table 1). Specifically, males showed significant variation in the number of head raises $\left(F_{2,8}=13.07, P=0.003\right)$ and pauses $\left(F_{2,8}=6.01, P=0.025\right)$ (Fig. 5). Head raises were most frequent in the male versus female trials $(9.2$ $\pm 1.83)$ compared to the male-only $(3.4 \pm 0.92 ; q=7.22$, $P=0.002)$ and female-only trials $(6.5 \pm 1.51 ; q=3.36$, $P=0.045)$. Head raises were also higher in female-only compared to male-only $(q=3.86, P=0.026)$. Males paused most frequently in female-only $(8.0 \pm 0.79)$

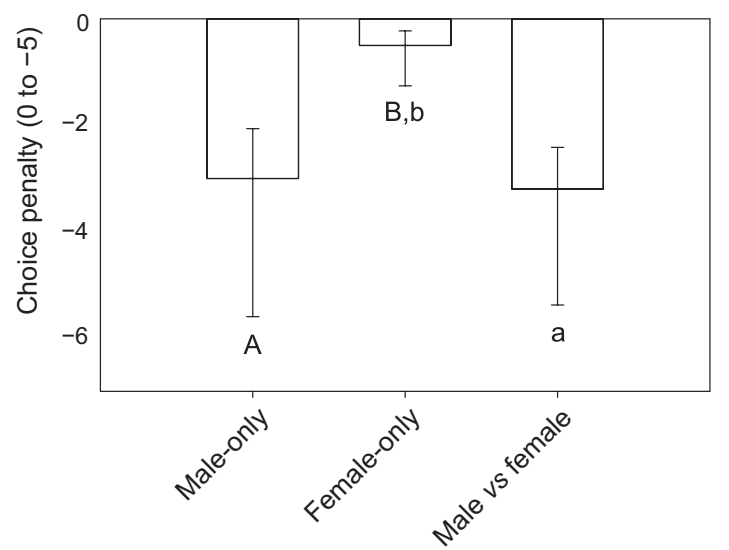

Figure 3 Male Burmese pythons $(n=5)$ explored the unscented arm of the maze more thoroughly in the male-only trials than female-only; therefore, they received a more negative choice penalty score. When both male and female scent trails were present, the males explored the male-scented arm (non-target) more extensively than in female-only. Bars represent means. Positive error is SEM, negative is $95 \%$ confidence interval. Uppercase letters are significant differences $(P<0.05)$; lowercase letters are marginally significant $(0.05<P<0.10)$. compared to male-only $(4.7 \pm 1.03 ; q=4.65, P=0.027)$ and male versus female $(5.4 \pm 0.92 ; q=3.66, P=0.032)$ (male-only $v$ male-female, $q=0.98, P=0.50$ ). There were no significant differences in turns $\left(F_{2,8}=1.71, P=\right.$ $0.24)$ or head shakes $\left(F_{2,8}=0.91, P=0.43\right)$.

Trailing behaviors occurred in predictable sequences, and the dominant sequence was head shake to pause to head raise as depicted in an ethogram (Fig. 6). Relative to male-only trials, additional behavior sequences were seen in female-only and male $v s$ female trials, with many sequences increasing in frequency (Table 2).

\section{DISCUSSION}

Our results show that male Burmese pythons recognize and follow scent trails from females in a Y-maze. Chemical and tactile information are of central importance to snakes, and their general reliance on other sensory information is believed to be limited (Ford 1995). Male pythons showed increased chemosensory sampling of female scent trails via tongue-flicking which strongly suggests that chemical communication is the mechanism by which these snakes locate potential mates in the environment, as is true of virtually all snake species studied (Ford 1986; Mason 1992; Mason \& Parker 2010;

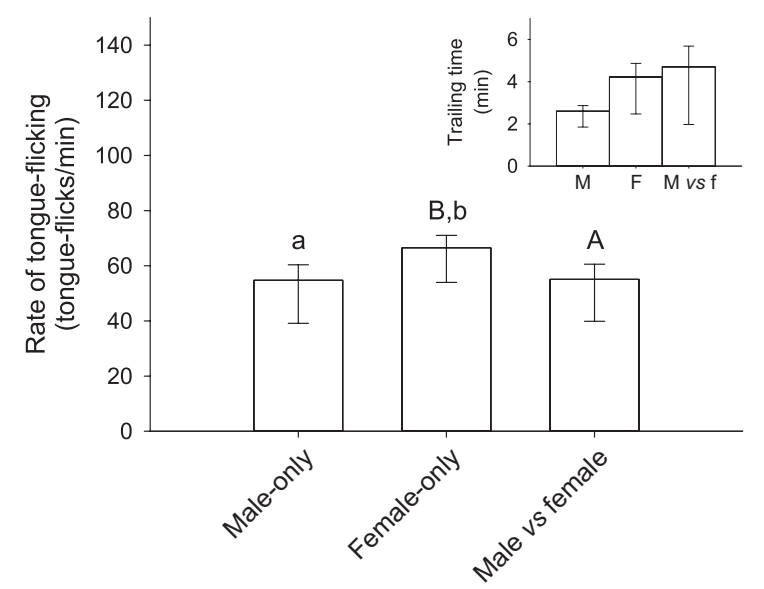

Figure 4 Male Burmese pythons $(n=5)$ had higher rates of chemosensory sampling (rates of tongue-flicking) when following female scent trails alone than when they were paired with male scent trails. Inset: Trailing times did not differ across the trials. Bars represent means. Positive error is SEM, negative is $95 \%$ confidence interval. Uppercase letters are significant differences $(P<0.05)$; lowercase letters are marginally significant $(0.05<P<0.10)$. 
Figure 5 Male Burmese pythons ( $n=$ 5) showed a variety of behaviors in the Y-maze across all trials. Only pausing and head raising showed significant variation between trial type. Males paused most often when only female trails were present. Head raising behavior was most frequent when males discriminated between female and male scent trails simultaneously. Bars represent means. Positive error is SEM, negative is $95 \%$ confidence interval. Letters are significant differences $(P<0.05)$.
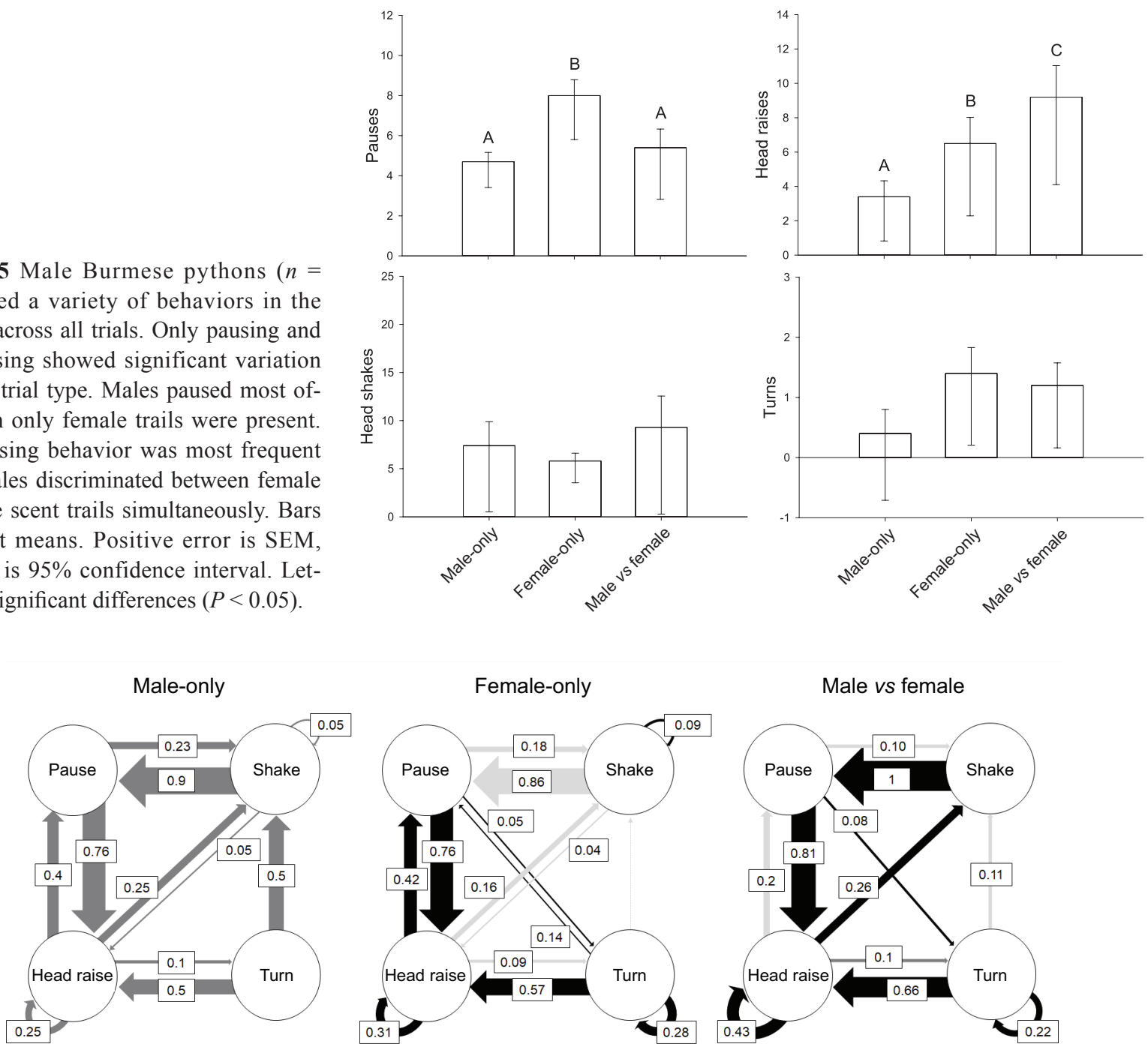

Figure 6 Kinematic diagram illustrating behavioral sequences of male pythons $(n=6)$ in different conspecific scent trailing scenarios. Numbers indicate the frequency of a behavior following another (arrow points to subsequent behavior; size of arrow indicates magnitude of frequency). Black arrows are behavioral sequences that increased in frequency compared to the male-only trials; lighter gray arrows decreased.

Table 2 Differences in the frequencies of behavioral sequences from male Burmese pythons $(n=5)$ relative to male-only Y-maze trials

\begin{tabular}{|c|c|c|c|c|c|c|c|c|}
\hline \multirow{3}{*}{$\begin{array}{l}\text { 1st behavior } \\
\text { Male-only } \\
\text { (reference) }\end{array}$} & \multicolumn{8}{|l|}{ 2nd behavior } \\
\hline & \multicolumn{2}{|l|}{ Pause } & \multicolumn{2}{|l|}{ Head shake } & \multicolumn{2}{|l|}{ Head raise } & \multicolumn{2}{|l|}{ Turn } \\
\hline & Female-only & $\begin{array}{l}\text { Male } v s \\
\text { female }\end{array}$ & Female-only & $\begin{array}{l}\text { Male } v s \\
\text { female }\end{array}$ & Female-only & $\begin{array}{l}\text { Male } v s \\
\text { female }\end{array}$ & Female-only & $\begin{array}{l}\text { Male } v s \\
\text { female }\end{array}$ \\
\hline Pause & 0 & 0 & -0.054 & -0.13 & 0.001 & 0.049 & 0.053 & 0.081 \\
\hline Head shake & -0.036 & 0.1 & 0.041 & -0.05 & -0.005 & -0.05 & 0 & 0 \\
\hline Head raise & 0.029 & -0.2 & -0.084 & 0.017 & 0.06 & 0.183 & -0.005 & 0 \\
\hline Turn & 0.143 & 0 & -0.5 & -0.389 & 0.071 & 0.167 & 0.286 & 0.222 \\
\hline
\end{tabular}

The first column indicates first behavior, and each subsequent column represents the sequential behavior. Gray cells are behavior sequences that decreased relative to male-only. 
Parker \& Mason 2011).

Male Burmese pythons following female scent showed specific changes in their searching behaviors (head raises, pauses). We believe head raising is a generalized searching pattern where males are looking for either additional chemical signals or other potential cues from females (e.g. visual cues and movement). In the wild, vertical exploration is possible for male Burmese pythons, and this species climbs trees and basks in arboreal habitats (Reed \& Rodda 2009). Captive Indian rock pythons [Python sebae (Gmelin, 1788)] displayed a "head up posture" when reproductively active, with males lifting their heads $30-60 \mathrm{~cm}$ above the substrate (Walsh \& Murphy 2003). It may be that the head raises we observed are the same. Breeding males of other snake species exhibit periscoping behavior to search for females, and in this behavior trailing males quickly raise their heads and scan the horizon to possibly hone searching (garter snakes, Shine et al. 2005). It has also been suggested that head raises in Indian pythons $[P y-$ thon molurus (Linnaeus, 1758)] function as sexual signals (Barker et al. 1979).

In contrast, pausing behavior in the pythons may serve to allow processing time at the neural level for assessing chemical cues. In countless examples, snakes pause when encountering a new chemical trail before exhibiting additional behaviors (reviewed in Mason 1992). In an elegant example, male garter snakes determined a female's movement vector by assessing the side of a wooden post she used to propel herself in a maze. The males rapidly tongue-flicked the sides of the post, then propelled from the female side to follow the female's trajectory (Ford \& Low 1984).

Head shakes and turns by male Burmese pythons are not scent-trail specific, and we propose that these behaviors are general components of the searching repertoire of Burmese pythons. Head shakes may be useful for chemosensation by disrupting the chemical environment of the substrate to waft additional cues for detection and assessment. In Walsh and Murphy (2003), male pythons (P. sebae) exhibited "jerky side-to-side motion" along the females' bodies during courtship, which are observed in many species of snakes during courtship (Carpenter 1977; Greene \& Mason 2000; Senter et al. 2014). We observed head shakes regardless of the scent present, so we cannot ascribe an alternate function. Turns were rarely observed compared to the other behaviors but were recorded based on previous work in rattlesnakes that used turning behavior as a proxy for certainty while trailing (Parker \& Kardong 2006; 2017).
Based on our ethograms, we intuit that the increased interactions between behaviors in female-only trials reflects stronger male response to female scent. Behavioral sequence diagrams for other species reliably inform researchers about qualities of an unknown chemical trail, such as sex, species, female receptivity and male fitness (Ford 1995). Sequences of courtship behavior have been described for 3 different rat snake species (genus Elaphe). The courtship behaviors were described triphasically with the behaviors varying slightly across each. Courtship sequences of the brown tree snake, the Indian python and the Burmese python have also been similarly described in 3 phases, but behavioral sequences have not been established (Gillingham \& Chambers 1982; Greene \& Mason 2000; Walsh \& Murphy 2003).

When male and female scent were present in the trailing environment, male Burmese pythons performed worse than if only female scent was present. Males increased searching in the non-target arm (choice penalty score), did not discriminate between trails (lack of choice and reduced tongue-flicking) and decreased their processing time (pausing). Either conflicting chemical stimuli from conspecifics impede proper mate trailing or, more likely, our male versus female trials occurred once males were no longer responsive to female scent. In other snakes (e.g. garter snakes), males respond to female pheromones only during the breeding season then switch exclusively to prey cue detection (O'Donnell et al. 2004). Males only become responsive to female pheromones again after prolonged low-temperature dormancy (e.g. Garstka et al. 1982). Conflicting stimuli significantly alter receiver detection and preference for a signal (e.g. Thompson et al. 2008), but our experimental timeline precludes us from further inference.

Our current study is the first on Burmese python chemical ecology; however, this species is not the only invasive snake in the USA. In Florida alone, there are multiple established invasive snake species, including Boa constrictor Linnaeus, 1758 and P. sebae (Krysko et al. 2011). Reticulated pythons [Malayopython reticulatus (Schneider, 1801)] and green anacondas (Eunectes murinus Linnaeus, 1758) have also been recorded in Florida but are not established. Boa constrictors are invasive in Puerto Rico and several Caribbean islands also (Reed \& Rodda 2011; Reynolds et al. 2013). In addition to large constrictors, smaller snakes are invasive, such as king snakes in the Canary Islands (Cabrera-Pérez et al. 2012) and northern water snakes in California (Rose et al. 2013). Ultimately, the threat posed by invasive snakes is their propensity to shift diets rapidly in new 
environments and function as second-order if not apex predators in novel habitats. Considerable research effort is thus warranted to decipher the mechanisms that enable snakes to thrive in their non-native habitats, especially the ways in which invasive snakes locate and select their mates.

\section{ACKNOWLEDGMENTS}

K. Keacher and W. Bruce provided animal care at the National Wildlife Research Center. Colleagues at the Florida Fish and Wildlife Conservation Commission, Miami-Dade Fire Rescue Venom Response Program, National Park Service, and University of Florida assisted in obtaining the wild-caught pythons. K. Rush assisted with identifying and describing behaviors. All procedures involving the use of pythons was approved by the IACUC of the National Wildlife Research Center. This research was supported through cooperative agreements 14-7412-1061-CA, 15-7412-1155-CA, and 167412-1269-CA between James Madison University and the U.S. Department of Agriculture's Animal and Plant Health Inspection Service (APHIS).

Conflict of Interest Statement: The authors declare no competing interests.

\section{REFERENCES}

Barker D, Murphy J, Smith K (1979). Social behavior in a captive group of Indian pythons, Python molurus (Serpentes, Boidae) with formation of a linear social hierarchy. Copeia 3, 466-71.

Bryant G, Bateman P, Fleming P (2011). Tantalising tongues: Male carpet pythons use chemoreception to differentiate among females. Australian Journal of Zoology 59, 42-8.

Cabrera-Pérez M, Gallo-Barneto R, Esteve I, Patiño-Martínez C, López-Jurado L (2012). The management and control of the California kingsnake in Gran Canaria (Canary Islands): Project LIFE+ Lampropeltis. Aliens: The Invasive Species Bulletin 32, 20-8.

Carmichael C, Kreiser B, Barker D, Barker T, Gillingham J (2007). Geographic variation in pheromone trailing behaviors of the Indonesian water python ( $\mathrm{Li}$ asis mackloti) of Indonesia's Lesser Sunda Archipelago. In: Henderson R, Powell R, eds. Biology of the Boas and Pythons. Eagle Mountain Publishing, Eagle Mountain, Utah, pp. 227-40.

Carpenter C (1977). Communication and displays of snakes. American Zoologist 17, 217-23.

Dorcas M, Willson JD, Reed RN et al. (2012). Severe mammal declines coincide with proliferation of invasive Burmese pythons in Everglades National Park. Proceedings of the National Academy of Science USA 109, 2418-22.

Dorcas M, Pittman S, Willson JD (2018). Burmese pythons. In: Pitt W, Beaseley J, Witmer G, eds. Ecology and Management of Terrestrial Vertebrate Invasive Species in the United States. CRC Press, Boca Raton, FL, pp. 135-62.

Engeman R, Jacobson E, Avery ML, Meshaka W (2011). The aggressive invasion of exotic reptiles in Florida with a focus on prominent species: A review. Current Zoology 57, 599-612.

Eriksson D, Wallin L (1986). Male bird song attracts females-A field experiment. Behavioral Ecology and Sociobiology 19, 297-9.

Ford N (1986). The role of pheromone trails in the sociobiology of snakes. In: Duvall D, Müller-Schwarze D, Silverstein RM, eds. Chemical Signals in Vertebrates, vol. 4. Springer, Boston, pp. 261-78.

Ford N (1995). Experimental design in studies of snake behavior. Herpetological Monographs 9, 130-39.

Ford N, Low J (1984). Sex pheromone source location by garter snakes: A mechanism for detection of direction in nonvolatile trails. Journal of Chemical Ecology 10, 1193-9.

Garstka W, Camazine B, Crews D (1982). Interactions of behavior and physiology during the annual reproductive cycle of the red-sided garter snake (Thamnophis sirtalis parietalis). Herpetologica 38, 104-23.

Gillingham J, Chambers J (1982). Courtship and pelvic spur use in the Burmese python, Python molurus bivittatus. Copeia 1982, 193-6.

Greene M, Mason RT (1998). Chemically mediated sexual behavior of the brown tree snake, Boiga irregularis. Ecoscience 5, 405-9.

Greene M, Mason RT (2000). Courtship, mating, and male combat of the brown tree snake, Boiga irregularis. Herpetologica 56, 166-75.

Greene M, Stark S, Mason RT (2001). Pheromone trailing behavior of the brown tree snake, Boiga irregularis. Journal of Chemical Ecology 27, 2193-201.

Harvey R, Brien M, Cherkiss M et al. (2008). Burmese pythons in South Florida, scientific support for invasive species management. University of Florida IFAS Publication Number, WEC-242, 8-17. 
Krysko K, Burgess J, Rochford M et al. (2011). Verified non-indigenous amphibians and reptiles in Florida from 1863 through 2010: Outlining the invasion process and identifying invasion pathways and stages. Zootaxa 3028, 1-64.

Lelito J, Fraser I, Mastro V, Tumlinson J, Baker T (2008). Novel visual-cue-based sticky traps for monitoring of emerald ash borers, Agrilus planipennis (Col., Buprestidae). Journal of Applied Entomology 132, 66874.

Mason RT (1992). Reptilian pheromones. In: Gans C, Crews D, eds. Biology of the Reptilia, vol 18. University of Chicago Press, Chicago, pp. 115-206.

Mason RT, Parker MR (2010). Social behavior and pheromonal communication in reptiles. Journal of Comparative Physiology A, Neuroethology, Sensory, Neural, and Behavioral Physiology 196, 729-49.

Mason RT, Fales H, Jones T, Pannell L, Chinn J, Crews D (1989). Sex pheromones in snakes. Science 245, 290-93.

Mason RT, Chivers D, Mathis A, Blaustein A (1998). Bioassay methods for amphibians and reptiles. In: Haynes KF, Millar JG eds. Bioassay Methods, vol 2. Springer, Boston, pp. 71-325.

Mathies T, Levine B, Engeman R, Savidge J (2013). Pheromonal control of the invasive brown treesnake: Potency of female sexual attractiveness pheromone varies with ovarian state. International Journal of Pest Management 59, 141-9.

McCleery R, Sovie A, Reed RN, Cunningham MW, Hunter M, Hart KM (2015). Marsh rabbit mortalities tie pythons to the precipitous decline of mammals in the Everglades. Proceedings. Biological sciences/The Royal Society 282, 20150120.

Moynan C, Neumann C, Welsh C (2016). The effect of gender, tone, and sound location on the response behavior of Neogobius melanostomus (Round goby) and the possibility of future trapping of this invasive species in Lake Superior. Zebrafish 13, 287-92.

Nagamoto J, Aonuma H, Hisada M (2005). Discrimination of conspecific individuals via cuticular pheromones by males of the cricket Gryllus bimaculatus. Zoological Science 22, 1079-88.

O’Donnell R, Shine R, Mason RT (2004). Seasonal anorexia in the male red-sided garter snake, Thamnophis sirtalis parietalis. Behavioral Ecology and Sociobiology 56, 413-9.

Parker MR, Kardong KV (2006). The role of airborne and substrate cues from non-envenomated mice during rattlesnake (Crotalus oreganus) post-strike trailing. Herpetologica 62, 349-56.

Parker MR, Kardong KV (2017). Airborne chemical information and context-dependent post-strike foraging behavior in Pacific rattlesnakes (Crotalus oreganus). Copeia 105, 649-56.

Parker MR, Mason RT (2011). Pheromones in snakes: History, patterns and future research directions. In: Sever D, Aldridge R, eds. Reproductive Biology and Phylogeny of Snakes. CRC Press, Boca Raton, FL, pp. 551-72.

Rasmussen LE, Schmidt M, Henneous R, Groves D, Daves G (1982). Asian bull elephants: Flehmen-like responses to extractable components in female elephant estrous urine. Science 217, 159-62.

Reed RN, Rodda G (2009). Giant constrictors: Biological and management profiles and an establishment risk assessment for nine large species of pythons, anacondas, and the boa constrictor, U.S. Geological Survey Open-File Report 2009-1202. U.S. Geological Survey, Reston, VA.

Reed RN, Rodda G (2011). Burmese pythons and other giant constrictors. In: Encyclopedia of Biological Invasions. University of California Press, Berkeley, CA, pp. 85-91.

Reed RN, Willson JD, Rodda G, Dorcas M (2012). Ecological correlates of invasion impact for Burmese pythons in Florida. Integrative Zoology 7, 254-70.

Reynolds G, Puente-Rolón A, Reed RN, Revell L (2013). Genetic analysis of a novel invasion of Puerto Rico by an exotic constricting snake. Biological Invasions 15, 953-9.

Rhen T, Crews D (2000). Organization and activation of sexual and agonistic behavior in the leopard gecko, Eublepharis macularius. Neuroendocrinology 71, 252-61.

Rose J, Miano O, Todd B (2013). Trapping efficiency, demography, and density of an introduced population of Northern watersnakes, Nerodia sipedon, in California. Journal of Herpetology 47, 421-7.

Senter P, Harris S, Kent D (2014). Phylogeny of courtship and male-male combat behavior in snakes. PLoS ONE 9, e107528.

Shine R, Phillips B, Waye H, LeMaster M, Mason RT (2003). Chemosensory cues allow courting male garter snakes to assess body length and body condition of potential mates. Behavioral Ecology and Sociobi- 
$\operatorname{ology} 5,162-6$.

Shine R, O'Donnell R, Langkilde T, Wall M, Mason RT (2005). Snakes in search of sex: the relationship between mate-locating ability and mating success in male garter snakes. Animal Behavior 69, 1251-8.

Slater P (1973). Describing sequences of behavior. In: Bateson P, Klopfer P eds. Perspectives in Ethology. Springer, Boston, pp. 131-53.

Smith B, Cherkiss M, Hart K et al. (2016). Betrayal: radio-tagged Burmese pythons reveal locations of conspecifics in Everglades National Park. Biological Invasions $18,3239-50$.

Snow R, Brien M, Cherkiss M, Wilkins L, Mazzotti F (2007). Dietary habits of Burmese python, Python molurus bivittatus, from Everglades National Park,
Florida. Herpetological Bulletin 101, 5-7.

Takács S, Gries R, Gries G (2017). Sex hormones function as sex attractant pheromones in house mice and brown rats. ChemBioChem 18, 1391-5.

Thompson J, Bissell A, Martins E (2008). Inhibitory interactions between multimodal behavioural responses may influence the evolution of complex signals. Animal Behavior 76, 113-21.

Walsh T, Murphy J (2003). Observations on the husbandry, breeding and behaviour of the Indian python. International Zoo Yearbook 38, 145-52.

Witzgall P, Kirsch P, Cork A (2010). Sex pheromones and their impact on pest management. Journal of Chemical Ecology 36, 80-100.

\section{Cite this article as:}

Richard SA, Tillman EA, Humphrey JS, Avery ML, Parker MR (2019). Male Burmese pythons follow female scent trails and show sex-specific behaviors. Integrative Zoology 14, 460-9. 